Articles published in the JCI carry an aura of prestige and importance that goes beyond individual medical disciplines. As investigative medicine progresses through the 21 st century, it is crucial that we preserve this attribute of the JCI. Physician-scientists are drawn more and more to narrow specialties. We need to maintain a community of scholars who are willing and anxious to read and absorb articles of medical science outside their own field. By preselecting articles that merit wide readership, the JCI fulfills an essential function. May the ASCI and the JCI flourish for another 100 years.

Address correspondence to: Joseph L. Goldstein or Michael S. Brown, University of Texas Southwestern Medical Center, 5323 Harry Hines Blvd., Rm. L5.238, Dallas, Texas 75390-9046, USA. Phone: (214) 648-2141; Fax: (214) 648-8804; E-mail: joe. goldstein@utsouthwestern.edu (J.L. Goldstein); mike.brown@ utsouthwestern.edu (M.S. Brown).

1. Brown, M.S., Faust, J.R., and Goldstein, J.L. 1975. Role of the low density lipoprotein receptor in regulating the content of free and esterified cholesterol in human fibroblasts. J. Clin. Invest. 55:783-793.

2. Brown, M.S., and Goldstein, J.L. 1974. Familial hypercholesterolemia: defective binding of lipoproteins to cultured fibroblasts associated with impaired regulation of 3-hydroxy-3-methylglutaryl coenzyme A reductase activity. Proc. Natl. Acad. Sci. U. S. A. 71:788-792.

3. Goldstein, J.L., Anderson, R.G.W., and Brown, M.S. 1979. Coated pits, coated vesicles, and receptor-mediated endocytosis. Nature. 279:679-685.

4. Goldstein, J.L., and Brown, M.S. 1997. The clinical investigator: bewitched, bothered, and bewildered - but still beloved. J. Clin. Invest. 99:2803-2812.

5. Goldstein, J.L., Anderson, R.G.W., Buja, L.M., Basu, S.K., and Brown, M.S. 1977. Overloading human aortic smooth muscle cells with low density lipoprotein-cholesteryl esters reproduces features of atherosclerosis in vitro. J. Clin. Invest. 59:1196-1202.
6. Shimano, H., et al. 1996. Overproduction of cholesterol and fatty acids causes massive liver enlargement in transgenic mice expressing truncated SREBP-1a. J. Clin. Invest. 98:1575-1584.

7. Brown, M.S., and Goldstein, J.L. 1975. Regulation of the activity of the low density lipoprotein receptor in human fibroblasts. Cell. 6:307-316.

8. Lang, P.D., and Insull, W.J. 1970. Lipid droplets in atherosclerotic fatty streaks of human aorta. J. Clin. Invest. 49:1479-1488.

9. Goldstein, J.L., Ho, Y.K., Basu, S.K., and Brown, M.S. 1979. Binding site on macrophages that mediates uptake and degradation of acetylated low density lipoprotein, producing massive cholesterol deposition. Proc. Natl. Acad. Sci. U. S. A. 76:333-337.

10. Brown, M.S., and Goldstein, J.L. 1983. Lipoprotein metabolism in the macrophage: implications for cholesterol deposition in atherosclerosis. Annu. Rev. Biochem. 52:223-261.

11. Steinberg, D., Parthasarathy, S., Carew, T.E., Khoo, J.C., and Witztum, J.L. 1989. Beyond cholesterol: modifications of low-density lipoprotein that increases its atherogenicity. N. Engl. J. Med. 320:915-924.

12. Wang, X., Sato, R., Brown, M.S., Hua, X., and Goldstein, J.L. 1994. SREBP-1, a membrane-bound transcription factor released by sterol-regulated proteolysis. Cell. 77:53-62.

13. Horton, J.D., Goldstein, J.L., and Brown, M.S. 2002. SREBPs: activators of the complete program of cholesterol and fatty acid synthesis in the liver.J. Clin. Invest. 109:1125-1131.

14. Engelking, L.J., et al. 2005. Schoenheimer effect explained - feedback regulation of cholesterol synthesis in mice mediated by Insig proteins. J. Clin. Invest. 115:2489-2498.

15. Ji, C., Chan, C., and Kaplowitz, N. 2006. Predominant role of sterol response element binding proteins (SREBP) lipogenic pathways in hepatic steatosis in the murine intragastric ethanol feeding model. J. Hepatol. 45:717-724.

16. You, M., Fischer, M., Deeg, M.A., and Crabb, D.W. 2002. Ethanol induces fatty acid synthesis pathways by activation of sterol regulatory element-binding protein (SREBP). J. Biol. Chem. 277:29342-29347.

17. Browning, J.D., and Horton, J.D. 2004. Molecular mediators of hepatic steatosis and liver injury. J. Clin. Invest. 114:147-152.

18. Brown, M.S., and Goldstein, J.L. 2008. Selective versus total insulin resistance: a pathogenic paradox. Cell Metab. 7:95-96.

\title{
Atlantic City memories
}

\author{
Franklin H. Epstein
}

Department of Medicine, Beth Israel Deaconess Medical Center and Harvard Medical School, Boston, Massachusetts USA.

\section{ASCI 100TH}

\begin{abstract}
Fifty years ago, the Atlantic City meetings, held the first week in May of every year, were attended by all the elite of American academic medicine and all who wanted to join that group. Part of the magic of those meetings was that professors and neophytes took each other seriously and talked to each other.
\end{abstract}

In the 1950 s and 1960 s, Atlantic City was an informal meeting place attended, the first week in May, by all the elite of academic medicine and all who wanted to join that group. There were many fewer academic physicians then than there are today. At Yale, for example, the entire full-time faculty in the Department of Internal Medicine had no more than 20 members, comparable, perhaps, to the number in a division within such a department today. Specialists in one branch of medicine usually felt some obligation to keep up an interest in new advances in other branches, though one tuberculosis specialist once told me, "With me, everything below the diaphragm is strictly for pleasure." The Boardwalk, spacious and sunny, was the place to hang out, to meet your friends, and to catch glimpses of the leaders of scientific medicine in their relaxed moments. For many years, the headquarters of the three societies that met together in Atlantic City, dubbed "Young Squirts" (American Federation for Clinical

Conflict of interest: The author has declared that no conflict of interest exists. Citation for this article: J. Clin. Invest. 118:1222-1223 (2008). doi:10.1172/JCI34654.
Research [AFCR]), "Young Turks" (American Society for Clinical Investigation), and "Old Farts" (Association of American Physicians), was the Haddon Hall Hotel. Invitation to breakfast with a senior academic physician at Haddon Hall was a well-recognized recruitment maneuver.

To have an abstract accepted for oral presentation at the meeting of the Young Turks was a prized accolade that made the long days of a slow accumulation of data seem worthwhile. There were always questions afterward, sometimes by authorities whose names you recognized and whose papers or chapters you had actually read.

After the Young Turks' day of scientific papers (at Haddon Hall or, later, at the Steel Pier), the accepted procedure was to crowd into the bar of the Hotel Brighton for one or more Brighton Punches, a lethal rum-fruit juice combination designed to promote irreverence (Figure 1). Then one went to Hackney's or Cap't Starn's Seafood Restaurant at the extreme north end of the Boardwalk for a dinner that always included a dozen oysters and a grilled lobster. 


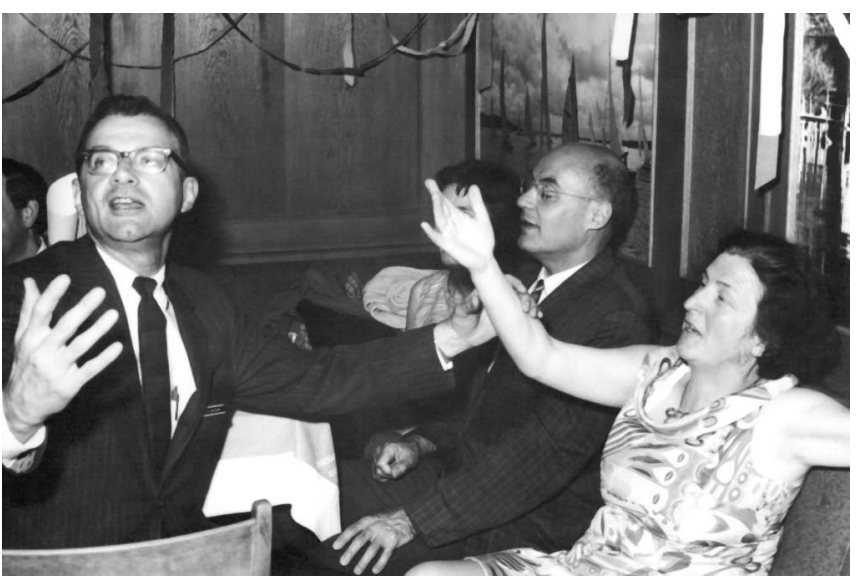

Three Atlantic City experiences stand out in my memory. In 1948, I attended the presentation by Philip S. Hench of the Mayo Clinic, who first introduced cortisone treatment of rheumatoid arthritis. It took place in one of the ballrooms of the old Haddon Hall Hotel, and the big room was packed. Before your eyes, there were pictures of formerly crippled, immobile patients who got up and walked. It was like a biblical miracle. At the conclusion of the 10-minute talk, the audience stood and applauded. Everyone felt that they had witnessed something historic - and they had!

My second memory concerns the first paper I ever gave at the Atlantic City meetings. It was entitled "The antidiuresis of quiet standing," and it summarized experiments on myself, Arnold Relman, and other fellow residents and interns at Yale. A consequence of the antidiuresis of standing, of course, was the diuresis that occurs when lying down. In the audience was Henry Christian, then chief of Medicine at the Peter Bent Brigham Hospital, the founder of the AFCR, and one of the original Young Turks. He raised his hand to make the first comment during the question period. As he rose to his full height of more than six feet, his great bald head gleaming in the light, I grew more nervous. "Now

\section{Figure 1}

Typical celebrants at the conclusion of an $\mathrm{ASCl}$ meeting in Atlantic City in the 1950s. Left to right: Franklin H. Epstein (later William Applebaum Professor of Medicine at Harvard Medical School and Physician-in-Chief, Beth Israel Deaconess Hospital, Boston), Alexander Leaf (later Jackson Professor of Medicine at Harvard Medical School and Physician-in-Chief, Massachusetts General Hospital), and Sheila Sherlock (later Dame Sheila Sherlock and Physician-in-Chief, Royal Free Hospital, London). The face of Leaf's wife, Barbara, is hidden by Sherlock's hand.

I finally understand," he rumbled, "why I have to get up to urinate only two hours after lying down."

In my third memory, I am riding an elevator in the Haddon Hall Hotel. The elevator car is crowded with medical academics and would-be academics. I am standing next to a large, rumpled, distinguished-looking man, whom I recognize immediately as William Castle, professor of Medicine at Harvard and director of the famous Thorndike Memorial Laboratory at the Boston City Hospital. The elevator stops at my floor, and I prepare to get out. Before I do, the large man grasps my hand and says, "Dr. Epstein, Bill Castle. I enjoyed your talk." I mumble thanks and leave the elevator on a cloud. What a nice man! He made my day, my week, my year!

What contributed to the magic of the Atlantic City meetings? Partly the sense that the presentations were the best that American academic medicine could produce. Partly that the presentations were taken seriously and questioned critically. Partly that professors, fellows, and neophytes walked and sunned themselves on the same Boardwalk and even talked to each other. They talked with each other! That is a tradition of the Young Turks that is worth preserving!

Address correspondence to: Franklin H. Epstein, Department of Medicine, Renal Division, Dana Building, Suite 517, Beth Israel Deaconess Medical Center, 330 Brookline Avenue, Boston, Massachusetts 02215, USA. Phone: (617) 667-4104; Fax: (617) 667-5276; E-mail: fepstein@bidmc.harvard.edu.

\title{
The American Society for Clinical Investigation - the first 100 years
}

\author{
Paul A. Marks \\ Cell Biology Program, Memorial Sloan-Kettering Cancer Center, New York, New York, USA.
}

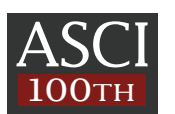

The annual Atlantic City meeting of the Young Turks was an exciting event - an opportunity to hear great science, to explore career opportunities, and to meet and make friends. Though the 1950s, '60s, and '70s, the meetings remained relatively intimate, broadly covering the best in medicine and constantly growing until the participants outgrew the Atlantic City venue to eventually spawn the numerous specialty annual meetings that we have today.

I attended my first meeting of the Young Turks (the ASCI) in 1953. As usual, it was held the first week in May in Atlantic City. There were at least three aspects of the Young Turks meetings

Conflict of interest: The author has declared that no conflict of interest exists. Citation for this article: J. Clin. Invest. 118:1223-1224 (2008). doi:10.1172/JCI34805. in Atlantic City that were important, indeed critical, to those of us aspiring to careers in academic medicine. The first was to be invited by your postdoctoral mentor - your first experience, and it truly was an experience - and remained so even as you grew old enough to get to an annual meeting on your own. After the first meeting, it became a required right of passage to attend annually. 